\section{A ATUALIDADE DA PSICANÁLISE}

Psicanalisar hoje, organizado por

Angélica Bastos. Rio de Janeiro: Contra Capa, 2006, 224 p.

Giselle Falbo

Psicanalista; doutora em Teoria Psicanalítica (UFRJ).

Psicanalisar hoje é o testemunho do compromisso daqueles que compõem o corpo docente e discente do Programa de Pós-Graduação em Teoria Psicanalítica da UFRJ que, reunidos pelos significantes que demarcam o campo psicanalítico — sem, no entanto, deixar de evidenciar posições distintas dentro do mesmo - fazem avançar questões cruciais abertas por Freud e que continuam a exigir esforço de elaboração.

Freud, em sua reflexão ética sobre a condição humana, ao se apropriar da expressão o "homem lobo do homem", situa no nível da estrutura um gozo mortífero: a pulsão de morte. Gozo que faz obstáculo ao estabelecimento de laços, e que solicita, a expensas de trabalho psíquico, a criação de uma "boa distância", mediação simbólica que regule a relação com o próximo; tensão não resolvida que comparece também no que há de mais íntimo, no coração do sujeito, por meio dos mandamentos insanos do supereu, os quais desafiam a psicanálise, tanto em sua vertente clínica quanto teórica. Com a postulação da pulsão de morte, a psicanálise se estende, como tratamento e pesquisa, para além das fronteiras estabelecidas pela arte da interpretação. Abraçando e localizando novos impasses e questões que, se de algum modo podem ser ditos atemporais, certamente se atualizam e se formulam de modos outros, ganhando novas feições e acento. Daí a necessidade de acrescentar ao "psicanalisar”, o “hoje”, já que a psicanálise não pode ser desatrelada de seu tempo.

Os textos reunidos no livro abordam, no melhor do estilo de cada um, isto que escapa ao sentido, que define o humano e que orienta a ética da psicanálise. Nesta direção, Joel Birman problematiza o forado-sentido inerente à passagem ao ato a partir do crime hediondo, do horror e do inapreensível desta porção do que há de mais humano: o inumano. Bruno Leal Farah, Daniel Mograbi, e Regina Herzog, ao fazer da crise e do mal-estar um ponto indissociável da produção da psicanálise, e afirmando a lógica da simultaneidade em lugar do ideal de superação, sustentam que associar os impasses que a clínica psicanalítica enfrenta à crise da autoridade é uma forma de tentar situar o "mau" do lado de fora e de nos rendermos ao imaginário progressista.

Com o auxílio do contraponto entre os encaminhamentos dados por Freud e Pavlov à herança legada por Descartes, distinguindo o modo particular como a psicanálise situa o fato psíquico, Anna Carolina Lo Bianco e Ricardo Sá desfa- 
zem o equívoco de se supor possível a aproximação entre a psicanálise e as neurociências ou às leituras cognitivistas das estruturas clínicas.

Waldir Beividas e Tiago Ravanello, questionando a proposição de um declínio da linguagem em favor do fora-do-sentido na progressão do ensino de Lacan, propõem a revisão das abordagens da linguagem e do real por meio da retomada do diálogo com a lingüística. Assumindo uma posição oposta, a partir de uma leitura decididamente clínica, Angélica Bastos e Ana Beatriz Freire introduzem a teoria lacaniana de alíngua. E apresentam a concepção de linguagem que lhe é correlata, de modo a situar sua pertinência para o tratamento psicanalítico, sobretudo em sua aplicação às psicoses e ao autismo.

Por intermédio da discussão sobre a psicanálise aplicada, Ana Cristina Figueiredo, Andréa Máris Campos Guerra e Doris Rangel Diogo examinam de que modo a psicanálise poderia contribuir na constituição de uma clínica ampliada em Saúde Mental, indicando a prática entre vários como alternativa aos impasses que a transferência nos impõe no trabalho com pacientes psicóticos.

Visando a verdade velada do discurso psiquiátrico sobre a fobia social, Teresa Pinheiro, Julio Verztman, Camilo Venturi e Mariana Barbosa, contrapondo vergonha e culpa, interrogam esta modalidade de mal-estar que coloca em cena, na relação com o outro, um olhar de reprovação. Já Fabiana Lustosa Gaspar e Martha Resende discutem o excesso na anorexia, quadro clínico que solicita uma lógica diversa do recalcamento e remete ao modo silencioso da pulsão de morte. Por sua vez, Maria Cristina Antunes e Tânia Coelho, por meio da teorização de Lacan sobre o Sinthoma, abordam a obesidade como um modo de tratamento dado ao excesso pulsional, advertindo sobre a possibilidade de desamarração em virtude das intervenções cirúrgicas que visam extirpar o sintoma.

Finalizando o leque de questões que compõem Psicanalisar hoje, Simone Perelson, com o objetivo de explicitar a particularidade do trágico contemporâneo, resgata o comentário de Lacan sobre a trilogia dos Coûfontaine de Claudel, fazendo uma leitura fina da qual extrai conseqüências para a ética da psicanálise e para a discussão sobre o final de análise.

Recebida em 21/6/2007.

Aprovada em 14/7/2007.

Giselle Falbo

gifalbo@ centroin.com.br 